\title{
Effectiveness of plasma treatment on pancreatic cancer cells
}

\author{
NORIFUMI HATTORI ${ }^{1}$, SUGURU YAMADA ${ }^{1}$, KOJI TORII $^{1}$, SHIGEOMI TAKEDA $^{1}$, KAE NAKAMURA $^{2}$, \\ HIROMASA TANAKA ${ }^{3}$, HIROAKI KAJIYAMA ${ }^{2}$, MITSURO KANDA ${ }^{1}$, TSUTOMU FUJII ${ }^{1}$, \\ GORO NAKAYAMA ${ }^{1}$, HIROYUKI SUGIMOTO ${ }^{1}$, MASAHIKO KOIKE ${ }^{1}$, \\ SHUJI NOMOTO $^{1}$, MICHITAKA FUJIWARA ${ }^{1}$, MASAAKI MIZUNO ${ }^{3}$, \\ MASARU HORI ${ }^{4}$ and YASUHIRO KODERA ${ }^{1}$
}

\begin{abstract}
Departments of ${ }^{1}$ Gastroenterological Surgery (Surgery II) and ${ }^{2}$ Obstetrics and Gynecology, ${ }^{3}$ Center for Advanced Medicine and Clinical Research, Nagoya University Graduate School of Medicine, Nagoya 466-8550;

${ }^{4}$ Plasma Nanotechnology Research Center, Nagoya University, Nagoya 464-8603, Japan
\end{abstract}

Received July 1, 2015; Accepted August 12, 2015

DOI: 10.3892/ijo.2015.3149

\begin{abstract}
Non-equilibrium atmospheric pressure plasma (NEAPP) has attracted attention in cancer therapy. We explored the indirect effect of NEAPP through plasmaactivated medium (PAM) on pancreatic cancer cells in vitro and in vivo. In this study, four pancreatic cancer cell lines were used and the antitumor effects of PAM treatment were evaluated using a cell proliferation assay. To explore functional mechanisms, morphological change and caspase-3/7 activation in cells were also assessed. Furthermore, reactive oxygen species (ROS) generation in cells was examined and $\mathrm{N}$-acetyl cysteine (NAC), an intracellular ROS scavenger, was tested. Finally, the antitumor effect of local injection of PAM was investigated in a mouse xenograft model. We found that PAM treatment had lethal effect on pancreatic cancer cells. Typical morphological findings suggestive of apoptosis such as vacuolization of cell membranes, small and round cells and aggregation of cell nuclei, were observed in the PAM treated cells. Caspase-3/7 activation was detected in accordance with the observed morphological changes. Additionally, ROS uptake was observed in all cell lines tested, while the antitumor effects of PAM were completely inhibited with NAC. In the mouse xenograft model, the calculated tumor volume on day 28 in the PAM treatment group was significantly smaller compared with the control group $[28 \pm 22$ vs. $89 \pm 38$ $\left.\left(\mathrm{mm}^{3} \pm \mathrm{SD}\right), \mathrm{p}=0.0031\right]$. These results show that PAM treat-
\end{abstract}

Correspondence to: Dr Suguru Yamada, Department of Gastroenterological Surgery (Surgery II), Nagoya University Graduate School of Medicine, 65 Tsurumai-cho, Showa-ku, Nagoya, Aichi 466-8550, Japan

E-mail: suguru@med.nagoya-u.ac.jp

Key words: apoptosis, non-thermal atmospheric pressure plasma, pancreatic cancer, reactive oxygen species, xenograft model antitumor assays ment of pancreatic cancer might be a promising therapeutic strategy.

\section{Introduction}

Pancreatic cancer is known to be the fifth most frequent cause of cancer-related death in Europe and the United States $(1,2)$. It is a lethal disease and the 5-year actual survival rate after potentially curative resection ranges between 8 and $19 \%$ (3-6). Multidisciplinary approach has been actively pursued to improve the outcome of this disease, but effective treatment strategy remains to be established.

Plasma is referred to as 'the fourth state of matter' that is subsequent to solid, liquid and gas, and resides in a highenergy state composed of negative electrons, positive ions, free radicals, excited molecules and energetic photons (7). Conventionally, plasma has been generated under high temperature and low pressure; however, owing to technical developments, non-equilibrium atmospheric pressure plasma (NEAPP), also known as cold plasma or non-thermal atmospheric pressure plasma, has actually entered into the realm of practical use (8).

Recently, NEAPP therapy has attracted attention as 'the fourth cancer therapy', which is subsequent to surgery, chemotherapy and radiotherapy. Previously, the antitumor effects of plasma have been reported in various cancer cell lines (7,9-12), and were thought to be associated with generation of reactive oxygen species (ROS), leading to DNA damage, cell cycle arrest and finally induction of apoptosis $(13,14)$. Because selective targeting of tumor cells is one of the most important aspects of anticancer therapy, some previous studies have reported on the direct effects of plasma treatment on cancer cells, although it might result in adverse effects on adjacent non-cancerous tissues $(12,15)$. In recent years, however, it has been reported that glioblastoma brain tumor cells and ovarian and gastric cancer cells could be selectively induced to undergo apoptosis when treated indirectly with plasma-activated medium (PAM) (16-18).

In the present study, selective antitumor effects of the PAM exposure on cell viability of pancreatic cancer cells were 
explored. Furthermore, the underlying mechanism whereby indirect plasma treatment could induce apoptosis was investigated. To the best of our knowledge, this is the first report to study the effectiveness of indirect plasma-activated medium exposure on pancreatic cancer cells.

\section{Materials and methods}

Cell lines and culture condition. Pancreatic cancer cell lines (PANC-1, Capan-2, BxPC-3 and MIA PaCa-2) were obtained from the American Type Culture Collection (Manassas, VA, USA) and maintained in RPMI-1640 medium supplemented with $10 \%$ fetal bovine serum (FBS), $100 \mathrm{U} / \mathrm{ml}$ of penicillin and $100 \mu \mathrm{g} / \mathrm{ml}$ of streptomycin (Life Technologies Corp., Grand Island, NY, USA). Normal human pancreatic duct epithelial cells (HPDE6/C7) were kindly provided by Dr Sarah Thayer (Massachusetts General Hospital, Boston, MA, USA). Cells were grown in keratinocyte serum-free medium (KSFM) (Life Technologies Corp.) containing $30 \mu \mathrm{g} / \mathrm{ml}$ bovine pituitary extract (BPE) and $0.2 \mathrm{ng} / \mathrm{ml}$ epidermal growth factor (EGF). All cells were cultured at $37^{\circ} \mathrm{C}$ in a humidified atmosphere with $5 \% \mathrm{CO}_{2}$.

Experimental system for production of PAM. The experimental system for production of PAM was described in a previous report (17). NEAPP with an ultra-high electron density $\left(\sim 2 \times 10^{16} \mathrm{~cm}^{-3}\right)$ was provided with an estimated $\mathrm{O}$ density of approximately $4 \times 10^{15} \mathrm{~cm}^{-3}(19,20)$. While argon gas was flowing, plasma in the discharge region was excited by applying $10 \mathrm{kV}$ from a $60-\mathrm{Hz}$ commercial power supply to two electrodes $8 \mathrm{~mm}$ apart (12). The flow rate of the argon gas was set at two standard liters/min (slm), and the separate distance between the plasma source and the medium (L) was fixed at $\mathrm{L}=15 \mathrm{~mm}$. Six ml of RPMI-1640 medium without 10\% FBS was placed in a $60-\mathrm{mm}$ dish and was treated with plasma at several exposure times ( $30 \mathrm{sec}, 1 \mathrm{~min}, 2 \mathrm{~min}, 3 \mathrm{~min}$ and $5 \mathrm{~min}$ ).

Cell proliferation assay. To evaluate the antitumor effects of PAM treatment, a WST-1 (Takara-Bio, Tokyo, Japan) cell proliferation assay was performed according to the manufacturer's instructions. Cells were seeded in a 96-well plate at a density of $1 \times 10^{3}, 5 \times 10^{3}$ and $1 \times 10^{4}$ cells per $100 \mu \mathrm{l}$ of culture medium. On the following day, the culture medium was replaced with $100 \mu \mathrm{l}$ of PAM. After PAM treatment for $24 \mathrm{~h}, 10 \mu \mathrm{l}$ of the WST-1 solution was added to each well and plates were incubated at $37^{\circ} \mathrm{C}$ for $90 \mathrm{~min}$. Absorbance at 440 and $630 \mathrm{~nm}$ was measured in a microplate reader. Each experiment was performed using six wells and repeated independently at least three times.

Cell apoptosis assay. To assess the effects of PAM treatment on cells, induction of apoptosis, morphological changes and caspase-3/7 activation were examined. Cells were seeded at a density of $5 \times 10^{4}$ cells/well in a 12 -well plate. The following day, the culture medium was replaced with PAM. Morphological changes were evaluated every few hours using light microscopy. Cells were also seeded in an 8-well imaging chamber at a density of $1 \times 10^{4}$ cells/well in $200 \mu 1$ of culture medium. The next day, the culture medium was replaced with $200 \mu 1$ of PAM or $200 \mu 1$ of RPMI-1640 as a control. After

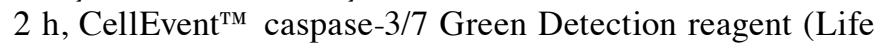

Technologies Corp.) was added to the wells. Three hours after PAM treatment, cells were observed under a Keyence BZ9000 microscope (Osaka, Japan).

Detection of intracellular ROS generation. Cells were seeded in an 8-well imaging chamber at a density of $1 \times 10^{4}$ cells/well in $200 \mu \mathrm{l}$ of culture medium. The following day, the culture medium was replaced with $200 \mu \mathrm{l}$ of PAM or $200 \mu 1$ of RPMI-1640 as a control. After $2 \mathrm{~h}$, the medium was replaced with $10 \mu \mathrm{M} \mathrm{CM}-\mathrm{H}_{2} \mathrm{DCFDA}$ (Life Technologies Corp.), and cells were incubated at $37^{\circ} \mathrm{C}$ in a humidified atmosphere with $5 \% \mathrm{CO}_{2}$. One hour later, cells were observed under a Keyence BZ9000 microscope (Osaka, Japan).

Cell proliferation assay with ROS inhibition. To assess the role of ROS generation in cells, the antitumor effects of PAM on pancreatic cancer cells treated with $\mathrm{N}$-acetyl cysteine (NAC, Sigma-Aldrich, St. Louis, MO, USA), an intracellular ROS scavenger, were examined. Cells were seeded in a 96-well plate at a density of $1 \times 10^{3}, 5 \times 10^{3}$ and $1 \times 10^{4}$ cells/ well in $100 \mu 1$ of culture medium. The next day, the culture medium was replaced with $100 \mu \mathrm{l}$ of PAM and $4 \mathrm{mM}$ NAC. Twenty-four hours later, $10 \mu 1$ of WST-1 solution was added to each well and the cell proliferation assay was performed.

Animal studies. Six-week-old male nude mice (BALB/C) $(\mathrm{N}=10)$ were obtained from Chubu Kagaku Shizai (Nagoya, Japan). A total of $5 \times 10^{3}$ Capan 2 cells were suspended in $50 \mu \mathrm{l}$ of RPMI-1640 and $150 \mu$ l of Matrigel (BD Biosciences, San Jose, CA, USA), and subcutaneously injected into the bilateral flank of mice. Then, mice were divided into a control group and a PAM-treated group. Mice in the control group received $200 \mu$ l of RPMI-1640, whereas the PAM-treated group received $200 \mu 1$ of PAM by subcutaneous injection. In this animal study, PAM was prepared as follows: $4 \mathrm{ml}$ of RPMI-1640 medium was placed in a $21-\mathrm{mm}$ dish and treated with plasma for $10 \mathrm{~min}$. The subcutaneous injection was performed thriceweekly starting $24 \mathrm{~h}$ after cell injection. To evaluate antitumor effects, the tumor volume was calculated using the formula: $\pi / 6 \times$ (largest diameter) $x$ (smallest diameter) ${ }^{2}$. At 29 days after cell injection, the mice were sacrificed and tumors were harvested and weighed. To assess pathological differences, hematoxylin-eosin (H\&E) staining of sections from paraffin-embedded tumors was examined. Animal studies were performed in accordance with the guidelines issued by the Animal Experimental Committee of Nagoya University, Graduate School of Medicine.

Statistical analysis. All data are presented as means \pm SD . Statistical analysis of the data was performed using a Student's t-test. p-values $<0.05$ were considered statistically significant.

\section{Results}

Effects of PAM on pancreatic cancer cells. Antitumor effects of PAM treatment on four pancreatic cancer cell lines, PANC-1, Capan-2, BxPC-3 and MIA PaCa-2, were examined using a cell proliferation assay. The results are shown stratified by the length of time culture medium was exposed to the NEAPP (Fig. 1A). When the culture medium was treated with 
A
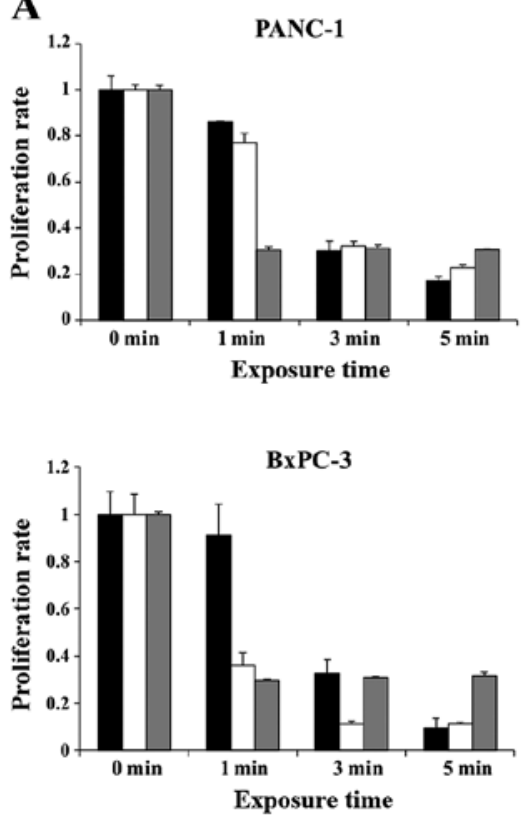
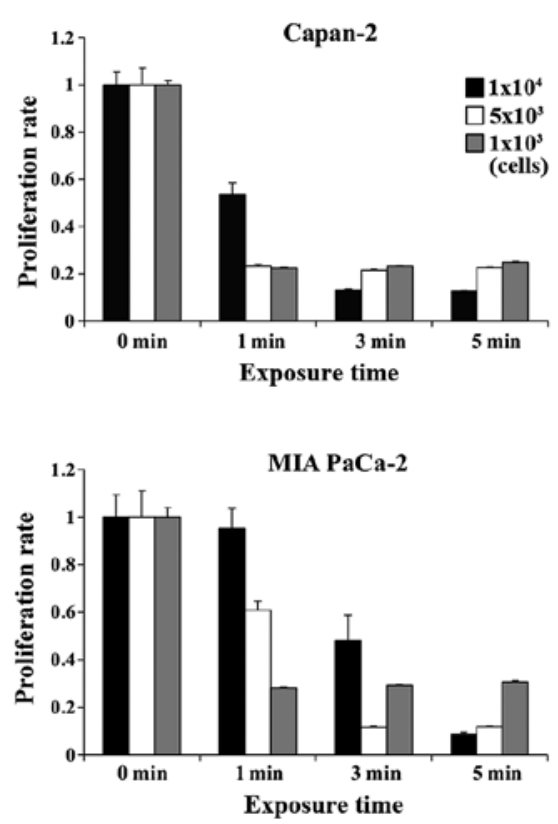

B

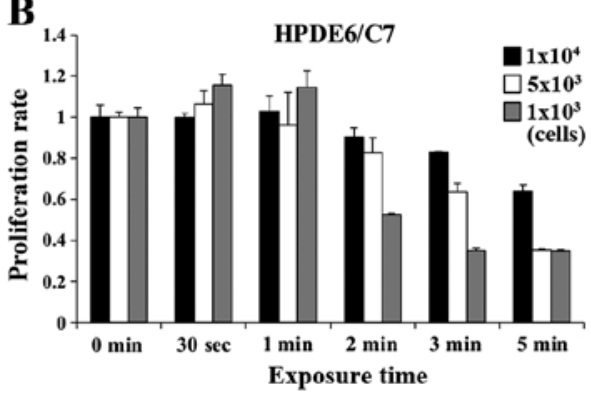

C

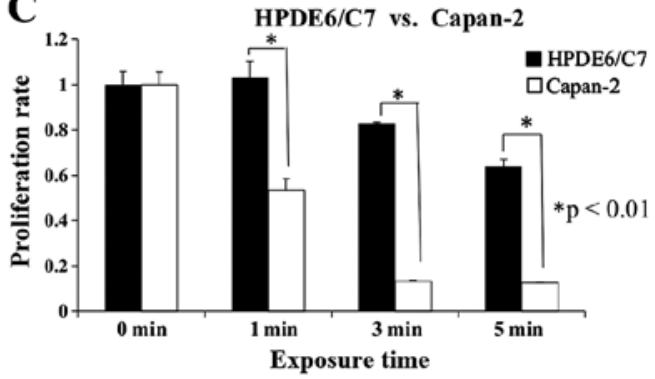

Figure 1. (A) Effects of plasma-activated medium (PAM) on pancreatic cancer cells. Pancreatic cancer cells (PANC-1, Capan-2, BxPC-3 and MIA PaCa-2) were seeded at a density of $1 \times 10^{3}, 5 \times 10^{3}$ and $1 \times 10^{4}$ cells/well in a 96-well plate. After PAM treatment for $24 \mathrm{~h}$, cell proliferation was evaluated using the WST-1 assay. (B) Effects of PAM on human pancreatic duct epithelial cells. Human pancreatic duct epithelial cells (HPDE6/C7) were seeded at a density of $1 \times 10^{3}, 5 \times 10^{3}$ and $1 \times 10^{4}$ cells/well in a 96-well plate. After PAM treatment for $24 \mathrm{~h}$, cell proliferation was evaluated using the WST-1 assay. (C) Comparison of cell viability (HPDE6/C7 vs. Capan2). PAM effectively killed pancreatic cancer cells (Capan2) in comparison with human pancreatic duct epithelial cells (HPDE6 C7).

NEAPP for $1 \mathrm{~min}, 1 \times 10^{3}$ cells of each cell line were effectively killed. However, when $5 \times 10^{3}$ or $1 \times 10^{4}$ cells were treated similarly, the cell proliferation assay showed differential sensitivity depending on the cell line. That is, $1 \times 10^{4}$ Capan- 2 cells were decreased by $47 \%$, whereas cells from other cell lines (PANC-1, BxPC-3 and MIA PaCa-2) were decreased by 4, 9 and $5 \%$, respectively. When the culture medium was treated with plasma for 3 or $5 \mathrm{~min}, 5 \times 10^{3}$ or $1 \times 10^{4}$ cells from every cell line were effectively killed by PAM.

Effects of PAM on human pancreatic duct epithelial cells. Next, to evaluate the effect of PAM on human pancreatic duct epithelial cells (HPDE6/C7), the cell proliferation assay was conducted (Fig. 1B). When the culture medium was treated with NEAPP for $\leq 1 \mathrm{~min}$, there was a $15 \%$ increase in cell proliferation. When the culture medium was treated with NEAPP for 5 min, cell proliferation decreased by $65 \%$ in wells with $1 \times 10^{3}$ and $5 \times 10^{3}$ cells, whereas it decreased by $37 \%$ in wells with $1 \times 10^{4}$ cells. When the cell proliferation rate was compared between HPDE6/C7 and Capan-2 cells, it was significantly higher for HPDE6/C7 than for Capan-2 cells, indicating low sensitivity of non-cancer cells to PAM (Fig. 1C).

Apoptosis induced by PAM treatment on pancreatic cancer cells. Morphological changes and caspase-3/7 activation in pancreatic cancer cells by PAM treatment were explored to assess the induction of apoptosis. Vacuolization of cell membranes and aggregation of cell nuclei as well as transformation into small and round cells were observed after $4 \mathrm{~h}$ of PAM treatment. Ultimately, most of the treated cells were deformed and shrunk, and some cells were detached from the dish after $24 \mathrm{~h}$, indicating typical morphological changes of apoptosis (Fig. 2). On the other hand, caspase-3/7 activation was detected in accordance with these morphological changes, as shown in Fig. 3. These results suggested that the antitumor effects of PAM could be attributed to cell apoptosis, rather than necrosis.

A mechanism of apoptosis induced by PAM treatment in pancreatic cancer cells. To better understand the underlying mechanism of apoptosis which occurred after PAM treatment, intracellular ROS generation in pancreatic cancer cell lines was investigated. After $3 \mathrm{~h}$ of PAM treatment, ROS uptake into every cell line was observed using fluorescence microscopy (Fig. 4). To assess the role of ROS generation in cancer cells, the effect of NAC, an intracellular ROS scavenger, over the antitumor activity of PAM were examined with the pancreatic cancer cell lines. The antitumor activity was completely inhibited in every cell line (Fig. 5), indicating that apoptosis caused by PAM treatment could be induced by intracellular ROS generation.

Antitumor effect of PAM on Capan2 tumor xenografts in mice. The antitumor effect of PAM treatment was investigated in a mouse xenograft model in which Capan2 cells were injected subcutaneously. Tumor formation was observed as early as day 10 post-cell injection in the control group, whereas it was not observed before day 14 in the PAM-treated group. The calculated tumor volume on day 28 in the PAM-treated group was significantly reduced compared with the control group $\left[28 \pm 22\right.$ vs. $\left.89 \pm 38\left(\mathrm{~mm}^{3} \pm \mathrm{SD}\right), \mathrm{p}=0.0031\right]$. The tumor weight on day 29 was significantly less in the PAM-treated group and 


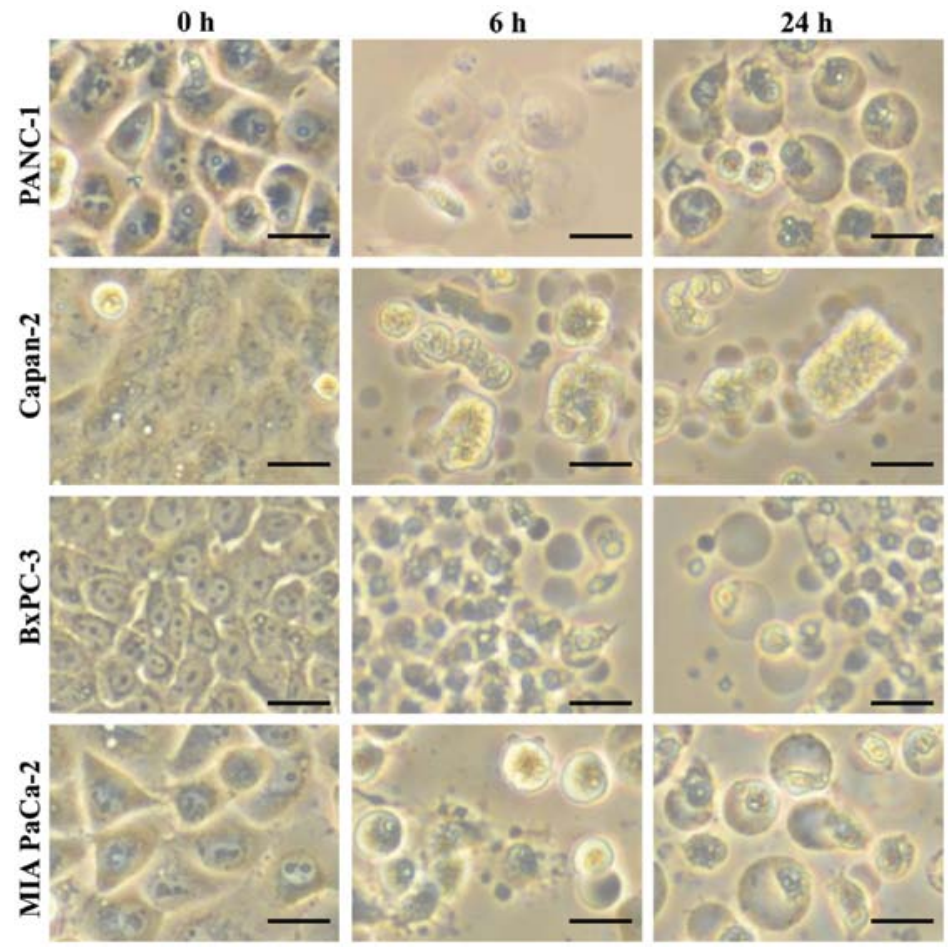

Figure 2. Morphological changes in pancreatic cancer cells after PAM treatment. Pancreatic cancer cells (PANC-1, Capan-2, BxPC-3 and MIA PaCa-2) were seeded at a density of $5 \times 10^{4}$ cells/well in a 12 -well plate. After $\sim 4 \mathrm{~h}$ of PAM treatment, vacuolization of cell membranes, small and round cells, and aggregation of cell nuclei were observed. Scale bars represent $25 \mu \mathrm{m}$.
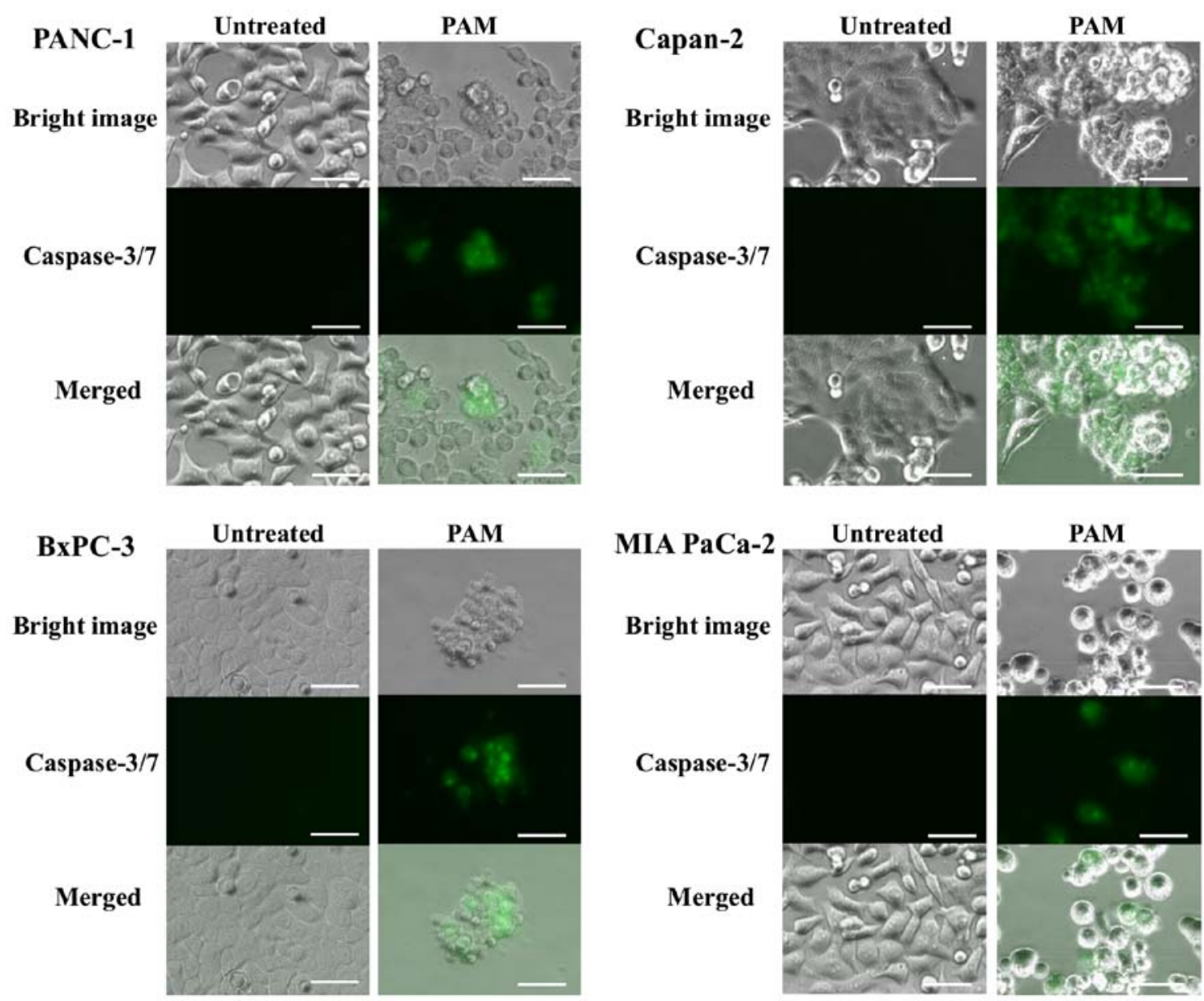

Figure 3. Caspase-3/7 activation in pancreatic cancer cells after PAM treatment. After PAM treatment, caspase-3/7 activation in pancreatic cancer cells (PANC-1, Capan-2, BxPC-3 and MIA PaCa-2) was observed using fluorescence microscopy. Caspase-3/7-positive cells in accordance with morphologically changed cells were observed. Scale bars represent $50 \mu \mathrm{m}$. 

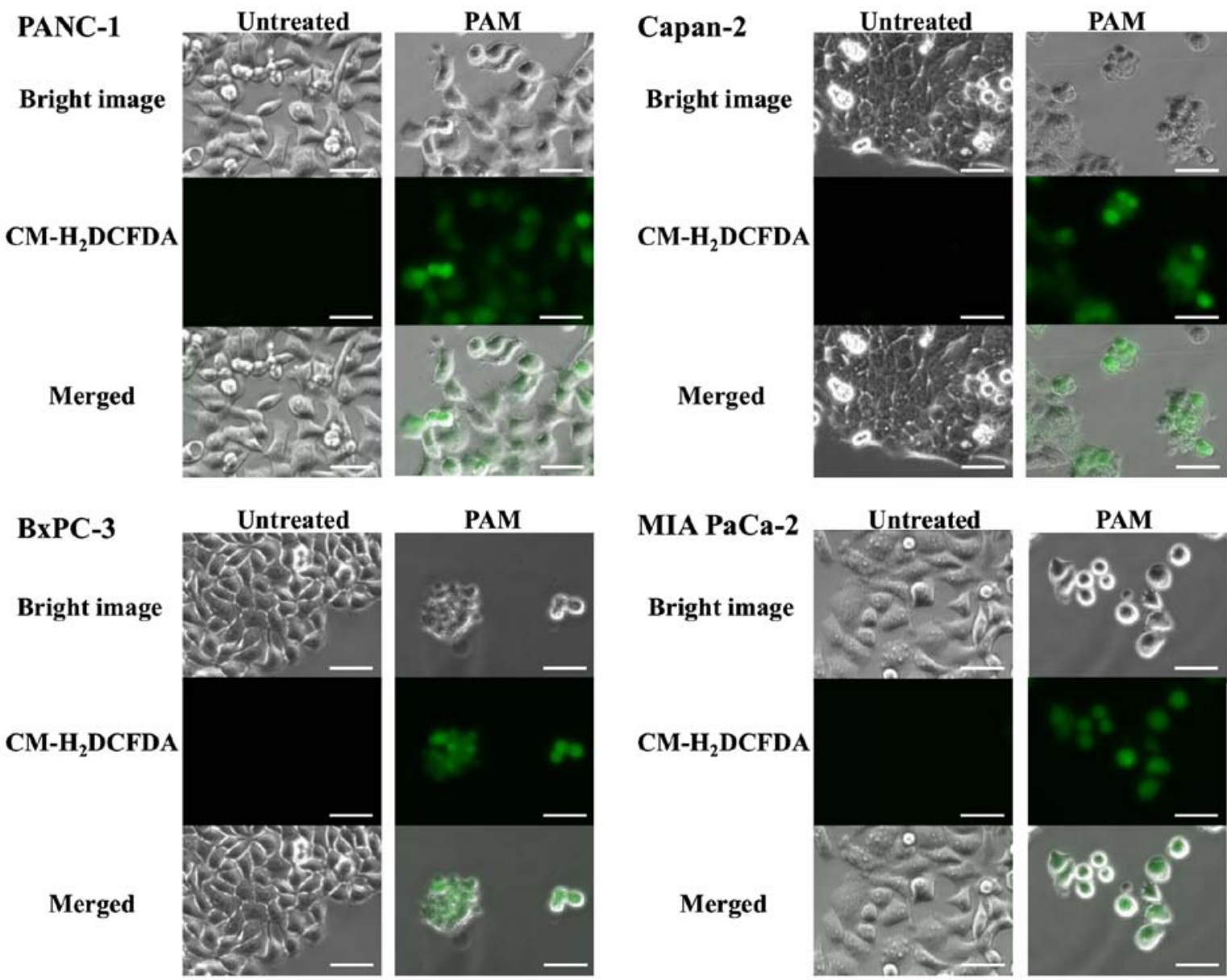

Figure 4. Detection of ROS in pancreatic cancer cells after PAM treatment. After PAM treatment, ROS uptake in pancreatic cancer cells (PANC-1, Capan-2, BxPC-3 and MIA PaCa-2) was observed using fluorescence microscopy. Scale bars represent $50 \mu \mathrm{m}$.

amounted to $64 \%$ of the control group $(\mathrm{p}=0.0018)$. Histological analysis of tumors from each group showed that $\sim 60 \%$ of tumor cells were degenerated in the PAM-treated group. No apparent adverse effects were observed in this animal study (Fig. 6).

\section{Discussion}

Pancreatic cancer has the worst prognosis of all gastrointestinal malignancies, and the difficulty of diagnosing the disease in its early stage results in $70-80 \%$ of patients being deemed unresectable, either because the disease is locally advanced or accompanied with distant metastasis $(21,22)$. Peritoneal dissemination is one of common pathway for metastasis in advanced pancreatic cancer. Although various effective anticancer drugs have been introduced into the clinical management of pancreatic cancer, the efficacy of these systemic chemotherapies remains elusive in the treatment of peritoneal metastasis. Recently, intraperitoneal administration of cytotoxic agents has been attempted in the treatment of peritoneal dissemination $(23,24)$, but its clinical impact remains to be evaluated.

Some previous reports have demonstrated that plasma could exert anti-proliferative effects on various cancer cells by inducing apoptosis $(10,25,26)$. Apoptosis is well known as programmed cell death that removes damaged cells; therefore, it serves as a crucial mechanism to defend tissues and organs from various types of stress and cell damage (27). Induction of apoptosis in cancer cells is beneficial compared with that of necrosis, because apoptosis does not cause inflammatory response that could influence adjacent normal cells as in the case of necrosis. In this study, PAM treatment was found to have anti-proliferative effects on pancreatic cancer cell lines through induction of apoptosis, as has been proved by typical morphological changes and caspase-3/7 activation.

Recent studies indicate that NEAPP can generate ROS, such as superoxide radicals $\left(\mathrm{O}_{2}^{-}\right)$, hydrogen peroxide $\left(\mathrm{H}_{2} \mathrm{O}_{2}\right)$, hydroxyl radicals $(\mathrm{OH})$ and nitric oxide $(\mathrm{NO})$, inducing apoptosis to the target cells $(14,28,29)$. In the present study, we found that ROS uptake was observed in all cell lines treated with PAM while the anti-proliferative effect of PAM was completely inhibited with NAC. NAC has been widely used as an antioxidant and directly scavenges hydroxyl radicals $(\mathrm{OH})$, hydrogen peroxide $\left(\mathrm{H}_{2} \mathrm{O}_{2}\right)$ and hypochlorous acid $(\mathrm{HClO})$ but not superoxide radicals $\left(\mathrm{O}_{2}^{-}\right)(30)$. Hence, the antitumor effects on pancreatic cancer cells might be caused by at least one of these ROS. More recently, Ninomiya et al demonstrated that NEAPP jets cause $\mathrm{OH}$ radical generation both in the liquid phase (extracellular culture medium) and within cancer cells, and consequently induce apoptotic cell death in breast cancer cell lines (31). Therefore, direct effect of NEAPP irradiation 

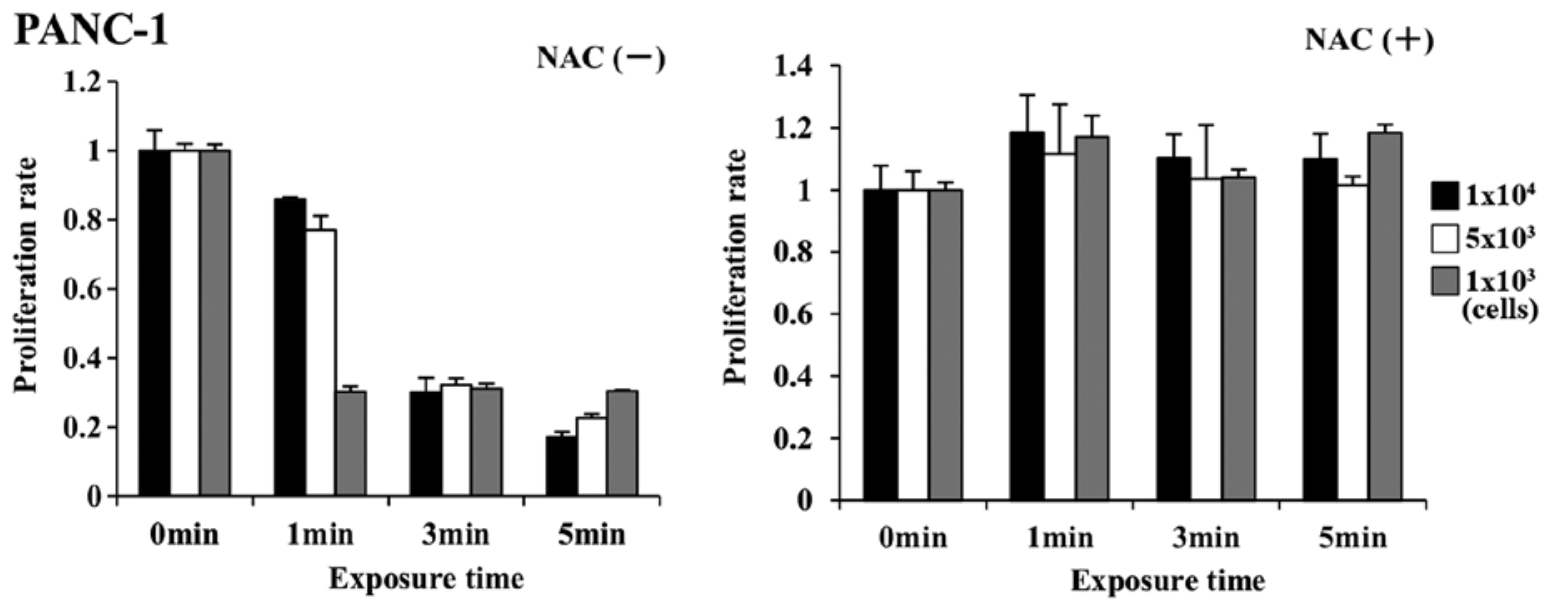

\section{Capan-2}
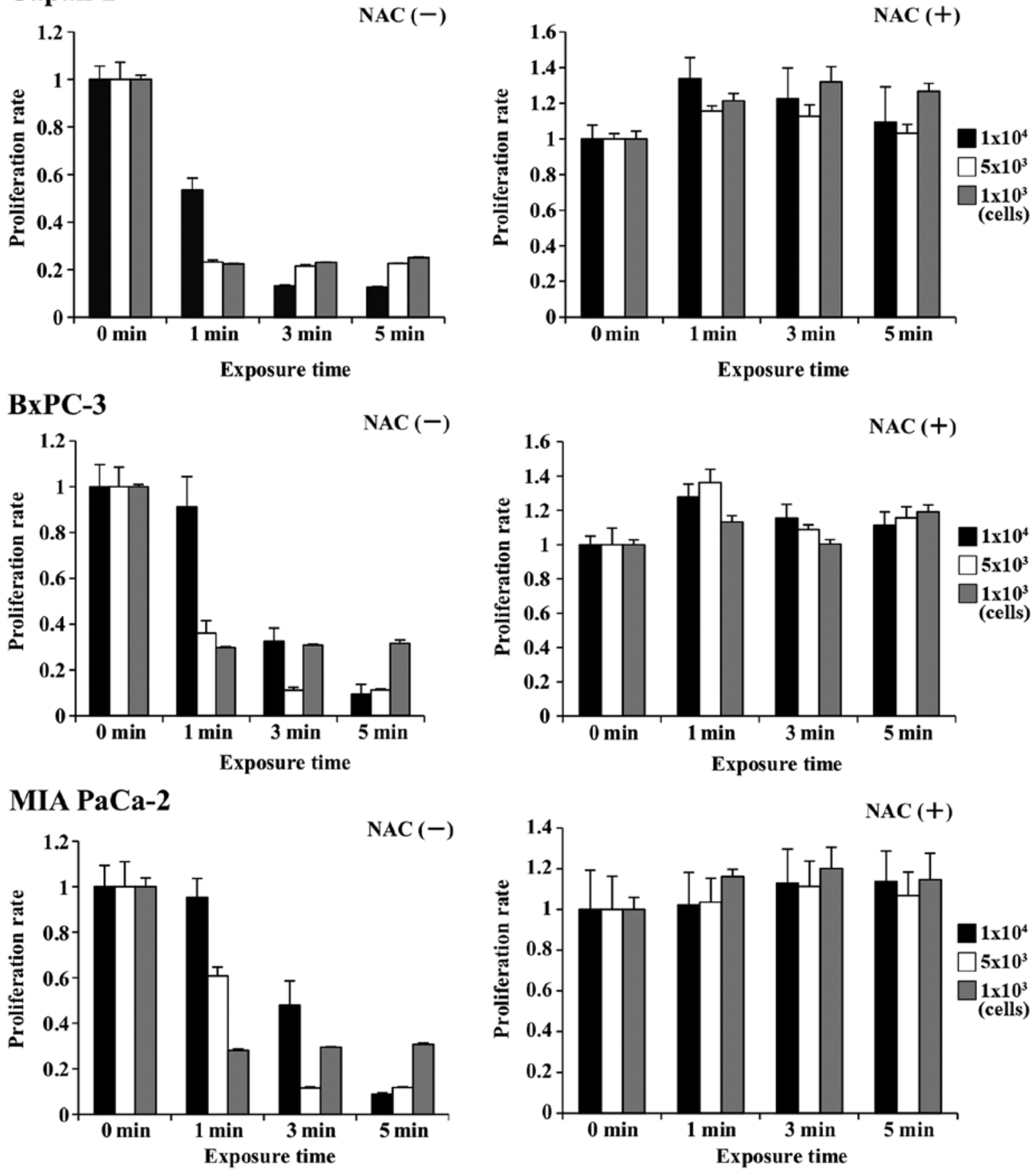

Figure 5. Influence of NAC on antitumor effect of PAM. Pancreatic cancer cells (PANC-1, Capan-2, BxPC-3 and MIA PaCa-2) were seeded at a density of $1 \times 10^{3}, 5 \times 10^{3}$ and $1 \times 10^{4}$ cells/well in a 96 -well plate. The following day, cell proliferation was evaluated using the WST-1 assay. 
A

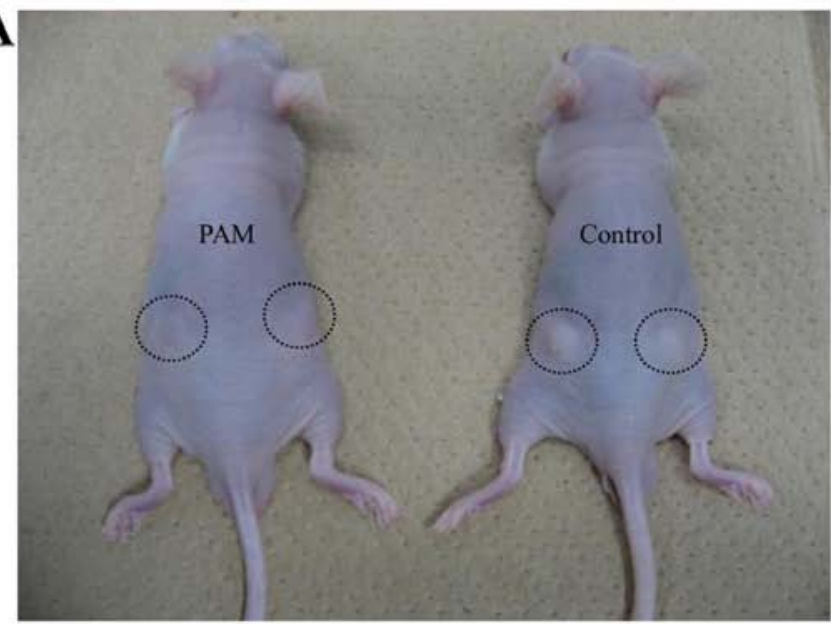

B

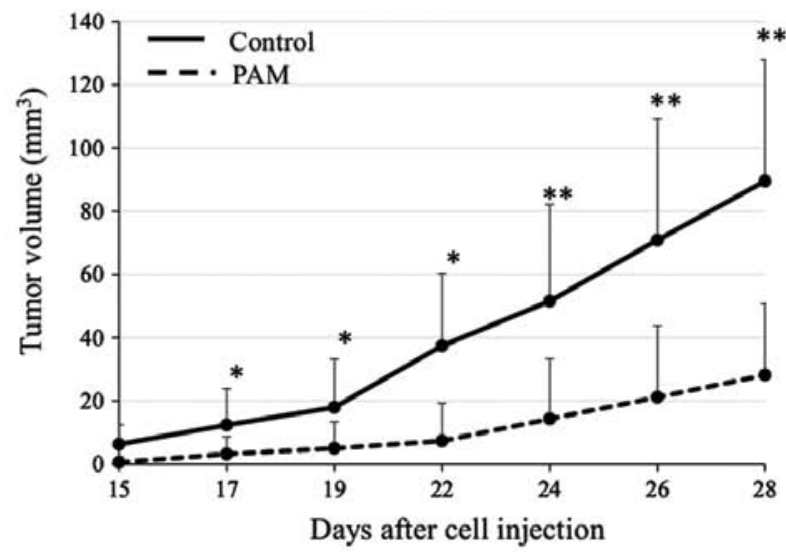

C

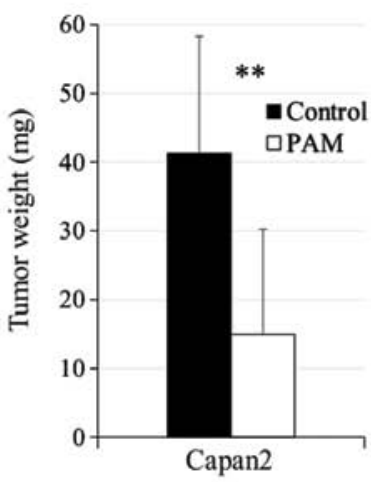

D

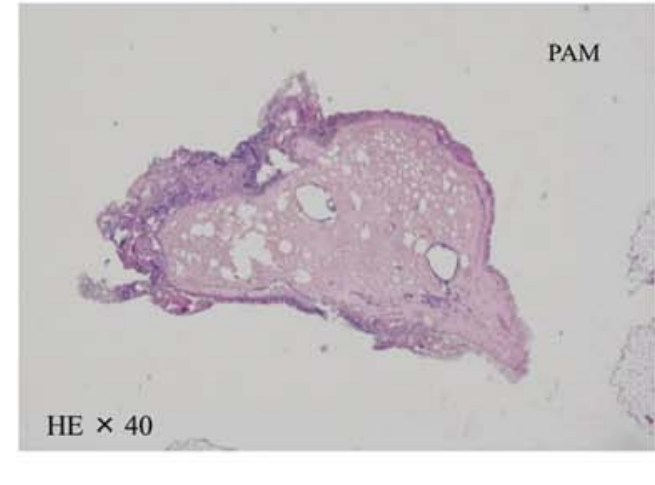

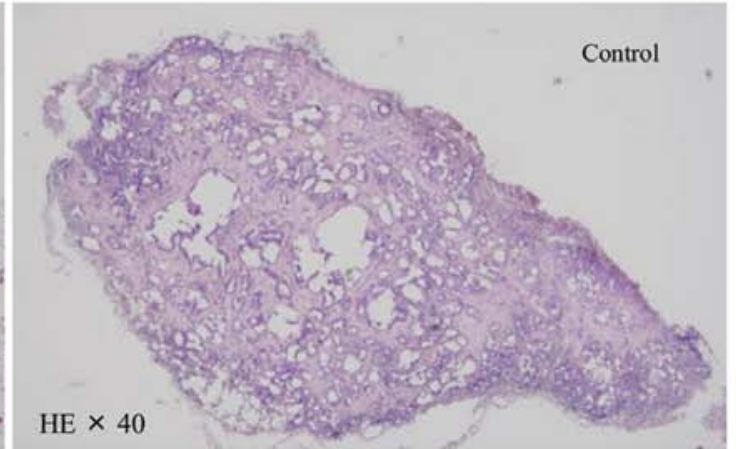

Figure 6. Antitumor effect of PAM on Capan2 tumor xenografts in a mouse model. Macroscopic tumor formation in each group. (B) Tumor growth curves of xenografts of Capan2 subcutaneous injections in each group are shown. Each point on the line represents the mean tumor volume and the bars represent the SD. ${ }^{*} \mathrm{p}<0.05,{ }^{* *} \mathrm{p}<0.01$. (C) The bar graph shows the mean tumor weight in each group. ${ }^{* *} \mathrm{p}<0.01$. (D) H\&E staining of tumor tissues in each group.

will also have to be explored in future through measurements of extracellular and intracellular ROS.

Some previous reports have demonstrated that there is a relationship between the level of ROS generation and the cell proliferation rate is complex $(32,33)$. Quite paradoxically, lower levels of ROS have been shown by some researchers to enhance rather than inhibit mitosis and cell proliferation $(34,35)$. In the present study, cell proliferation was actually increased by $15 \%$ in normal cells when exposed to plasma for a shorter period of time. The mechanism that induces the contradictory responses to the medium with short exposure to the NEAPP, cytotoxicity in pancreatic cancer cells and proliferation in normal cells, remains unclear.

The most problematic aspect of conventional cancer therapies, such as chemotherapy and radiotherapy, is unwanted adverse events caused by damage to the normal cells. However, previous reports looking at various plasma treatments documented their selective cytotoxicity to the tumor cells while leaving normal cells intact in ovarian cancer, glioblastoma and lung cancer $(12,14,16)$. Our results also showed that HPDE6/C7 cells were more tolerant to the PAM treatment than pancreatic cancer cells, although even HPDE6/C7 cells were killed when exposed to the PAM generated by long exposure to the NEAPP. In this regard, Barrera et al showed that normal cells were more tolerant to exogenous ROS stress, owing to their antioxidant reserve compared with cancer cells (36). The selective cytotoxicity of PAM treatment on cancer cells might offer a promising alternative approach in addition to the conventional anticancer therapies.

On the basis of our in vitro study, we also performed an in vivo animal study. We started PAM treatment $24 \mathrm{~h}$ postcell injection, and confirmed the effect of PAM on pancreatic cancer cells while they remain relatively small in number, mimicking micrometastasis. In a previous report, PAM inhibited the tumor growth of ovarian cancer cells in vivo (17); however, tumor growth was not completely inhibited by PAM. One reason for this result may have been that various ROS scavengers in the living organism neutralized some ROS generated by the plasma. In future experiments, we hope to use the PAM, both alone and in combination with cytotoxic agents or ROS scavengers, to treat peritoneal metastasis of in vivo model.

In conclusion, we demonstrated that PAM treatment, which induced apoptosis through intracellular ROS generation, had antitumor effects on pancreatic cancer cell lines. Furthermore, the cytotoxic effects were selective to cancer cells at optimal experimental conditions, showing potential of the PAM treatment as a novel mode of treatment for pancreatic cancer. 


\section{References}

1. Malvezzi M, Bertuccio P, Levi F, La Vecchia C and Negri E: European cancer mortality predictions for the year 2012. Ann Oncol 23: 1044-1052, 2012

2. Siegel R, Naishadham D and Jemal A: Cancer statistics, 2012. CA Cancer J Clin 62: 10-29, 2012.

3. Conlon KC, Klimstra DS and Brennan MF: Long-term survival after curative resection for pancreatic ductal adenocarcinoma. Clinicopathologic analysis of 5-year survivors. Ann Surg 223: 273-279, 1996

4. Schnelldorfer T, Ware AL, Sarr MG, Smyrk TC, Zhang L, Qin R, Gullerud RE, Donohue JH, Nagorney DM and Farnell MB Long-term survival after pancreatoduodenectomy for pancreatic adenocarcinoma: Is cure possible? Ann Surg 247: 456-462, 2008.

5. Ferrone CR, Pieretti-Vanmarcke R, Bloom JP, Zheng H, Szymonifka J, Wargo JA, Thayer SP, Lauwers GY, Deshpande V, Mino-Kenudson M, et al: Pancreatic ductal adenocarcinoma: Long-term survival does not equal cure. Surgery 152 (Suppl 1): S43-S49, 2012.

6. Winter JM, Brennan MF, Tang LH, D'Angelica MI, Dematteo RP, Fong Y, Klimstra DS, Jarnagin WR and Allen PJ: Survival after resection of pancreatic adenocarcinoma: Results from a single institution over three decades. Ann Surg Oncol 19: 169-175, 2012.

7. Vandamme M, Robert E, Pesnel S, Barbosa E, Dozias S, Sobilo J, Lerondel S, Le Pape A and Pouvesle J-M: Antitumor effect of plasma treatment on U87 glioma xnografts: Preliminary results. Plasma Process Polym 7: 264-273, 2010.

8. Yamazaki H, Ohshima T, Tsubota Y, Yamaguchi $H$, Jayawardena JA and Nishimura Y: Microbicidal activities of low frequency atmospheric pressure plasma jets on oral pathogens. Dent Mater J 30: 384-391, 2011.

9. Stoffels E, Kieft IE and Sladek REJ: Superficial treatment of mammalian cells using plasma needle. J Phys D Appl Phys 36: 2908,2003

10. Fridman G, Shereshevsky A, Jost MM, Brooks AD, Fridman A, Gutsol A, Vasilets V and Friedman G: Floating electrode dielectric barrier discharge plasma in air promoting apoptotic behavior in melanoma skin cancer cell lines. Plasma Chem Plasma Process 27: 163-176, 2007.

11. Kim CH, Bahn JH, Lee SH, Kim GY, Jun SI, Lee K and Baek SJ: Induction of cell growth arrest by atmospheric non-thermal plasma in colorectal cancer cells. J Biotechnol 150: 530-538, 2010.

12. Iseki S, Nakamura K, Hayashi M, Tanaka H, Kondo $H$ Kajiyama H, Kano H, Kikkawa F and Hori M: Selective killing of ovarian cancer cells through induction of apoptosis by nonequilibrium atmospheric pressure plasma. Appl Phys Lett 100: 113702,2012

13. Georgescu N and Lupu AR: Tumoral and normal cells treatment with high-voltage pulsed cold atmospheric plasma jets. Plasma Science. IEEE Trans 38: 1949-1955, 2010.

14. Keidar M, Walk R, Shashurin A, Srinivasan P, Sandler A, Dasgupta S, Ravi R, Guerrero-Preston R and Trink B: Cold plasma selectivity and the possibility of a paradigm shift in cancer therapy. Br J Cancer 105: 1295-1301, 2011.

15. Brullé L, Vandamme M, Riès D, Martel E, Robert E, Lerondel S, Trichet V, Richard S, Pouvesle JM and Le Pape A: Effects of a non thermal plasma treatment alone or in combination with gemcitabine in a MIA PaCa2-luc orthotopic pancreatic carcinoma model. PLoS One 7: e52653, 2012.

16. Tanaka H, Mizuno M, Ishikawa K, Nakamura K, Kajiyama $H$, Kano H, Kikkawa F and Hori M: Plasma-activated medium selectively kills glioblastoma brain tumor cells by down-regulating a survival signaling molecule, AKT kinase. Plasma Med 1: 265-277, 2011

17. Utsumi F, Kajiyama H, Nakamura K, Tanaka H, Mizuno M, Ishikawa K, Kondo H, Kano H, Hori M and Kikkawa F: Effect of indirect nonequilibrium atmospheric pressure plasma on antiproliferative activity against chronic chemo-resistant ovarian cancer cells in vitro and in vivo. PLoS One 8: e81576, 2013.
18. Torii K, Yamada S, Nakamura K, Tanaka H, Kajiyama $\mathrm{H}$, Tanahashi K, Iwata N, Kanda M, Kobayashi D, Tanaka C, et al: Effectiveness of plasma treatment on gastric cancer cells. Gastric Cancer 18: 635-643, 2015.

19. Iwasaki M, Inui H, Matsudaira Y, Kano H, Yoshida N, Ito M and Hori M: Nonequilibrium atmospheric pressure plasma with ultrahigh electron density and high performance for glass surface cleaning. Appl Phys Lett 92: p081503, 2008.

20. Jia F, Sumi N, Ishikawa K, Kano H, Inui H, Kularatne J, Takeda K, Kondo H, Sekine M, Kono A, et al: Laser scattering diagnosis of a $60-\mathrm{Hz}$ non-equilibrium atmospheric pressure plasma jet. Appl Phys Express 4: 026101, 2011.

21. Wray CJ, Ahmad SA, Matthews JB and Lowy AM: Surgery for pancreatic cancer: Recent controversies and current practice. Gastroenterology 128: 1626-1641, 2005.

22. Furuse J, Ishii $\mathrm{H}$ and Okusaka T: The Hepatobiliary and Pancreatic Oncology (HBPO) Group of the Japan Clinical Oncology Group (JCOG): History and future direction. Jpn J Clin Oncol 43: 2-7, 2013.

23. Ishigami H,Kitayama J, Kaisaki S, Hidemura A, Kato M, Otani K, Kamei T, Soma D, Miyato H, Yamashita H, et al: Phase II study of weekly intravenous and intraperitoneal paclitaxel combined with S-1 for advanced gastric cancer with peritoneal metastasis. Ann Oncol 21: 67-70, 2010

24. Takahara N, Isayama H, Nakai Y, Sasaki T, Ishigami H, Yamashita H, Yamaguchi H, Hamada T, Uchino R, Mizuno S, et al: Intravenous and intraperitoneal paclitaxel with S-1 for refractory pancreatic cancer with malignant ascites: An interim analysis. J Gastrointest Cancer 45: 307-311, 2014.

25. Kim G, Kim W, Kim K and Lee J: DNA damage and mitochondria dysfunction in cell apoptosis induced by nonthermal air plasma. Appl Phys Lett 96: 021502, 2010.

26. Ma Y, Ha CS, Hwang SW, Lee HJ, Kim GC, Lee KW and Song K: Non-thermal atmospheric pressure plasma preferentially induces apoptosis in p53-mutated cancer cells by activating ROS stressresponse pathways. PLoS One 9: e91947, 2014.

27. Elmore S: Apoptosis: A review of programmed cell death. Toxicol Pathol 35: 495-516, 2007.

28. Kalghatgi S, Kelly CM, Cerchar E, Torabi B, Alekseev O, Fridman A, Friedman $G$ and Azizkhan-Clifford J: Effects of non-thermal plasma on mammalian cells. PLoS One 6: e16270, 2011.

29. Sensenig R, Kalghatgi S, Cerchar E, Fridman G, Shereshevsky A, Torabi B, Arjunan KP, Podolsky E, Fridman A, Friedman G, et al: Non-thermal plasma induces apoptosis in melanoma cells via production of intracellular reactive oxygen species. Ann Biomed Eng 39: 674-687, 2011.

30. Aruoma O: Free radicals, oxidative stress, and antioxidants in human health and disease. J Am Oil Chem Soc 75: 199-212, 1998.

31. Ninomiya $K$, Ishijima $T$, Imamura $M$, Yamahara $T$, Enomoto $H$ Takahashi K, Tanaka Y, Uesugi Y and Shimizu N: Evaluation of extra- and intracellular $\mathrm{OH}$ radical generation, cancer cell injury, and apoptosis induced by a non-thermal atmospheric-pressure plasma jet. J Phys D Appl Phys 46: 425401, 2013.

32. Nicco C, Laurent A, Chereau C, Weill B and Batteux F: Differential modulation of normal and tumor cell proliferation by reactive oxygen species. Biomed Pharmacother 59: 169-174, 2005.

33. Nishikawa M: Reactive oxygen species in tumor metastasis. Cancer Lett 266: 53-59, 2008.

34. Arjunan KP,Friedman G,Fridman A and Clyne AM:Non-thermal dielectric barrier discharge plasma induces angiogenesis through reactive oxygen species. J R Soc Interface 9: 147-157, 2012.

35. Kalghatgi S, Friedman G, Fridman A and Clyne AM: Endothelial cell proliferation is enhanced by low dose non-thermal plasma through fibroblast growth factor-2 release. Ann Biomed Eng 38: 748-757, 2010.

36. Barrera G: Oxidative stress and lipid peroxidation products in cancer progression and therapy. ISRN Oncol 2012: 137289, 2012. 